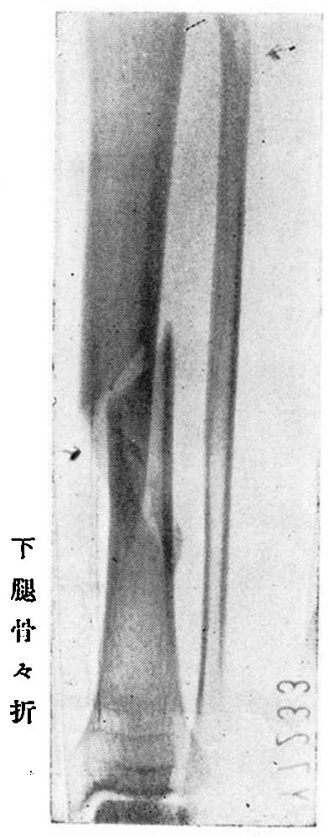

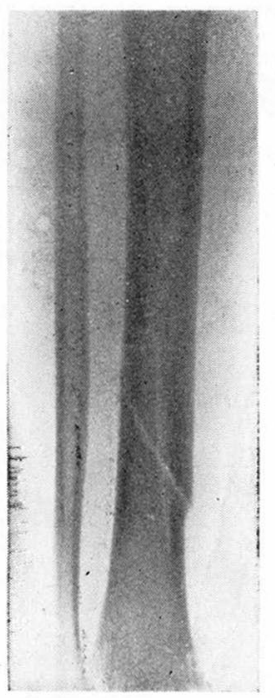

㗪形折

\section{主 要 交 献}

1. Wachsmuth. W. Deutsch. Med. Wschr. 61, 1084-1087, 1935.

2. 斉藤一男 日整会誌 $9,477-550$ 昭 8,9 年

3. 金田 他隐床外科 $9,125-127$ 昭 28 年

4. 高梨重武交通医学 $9,1,54-59$ 昭 30 年

5 . 諸富武交他臨床と研究 $32,1,50-55$ 昭 30 年

6. 野原道夫 岩手医学雑誌 6,6 , 196-199 昭 30 年

7. 䩡田幸徳他 日本医科大学雑誌 $32,843-849$ 昭 31 年

8. Bunnin 「足関節の外傷」 London 1559

9.ヤコブ 米国スポーツ・イラズトレーテット誌 (オールスポーツ

昭利 32 年 1 月 9 日より引用)

（第 13 回 主要文献妕常厂正）

J. G. Bonnin "Injuries to the Ankle" William Heinemann. Medical Books. LTD. London 1950.

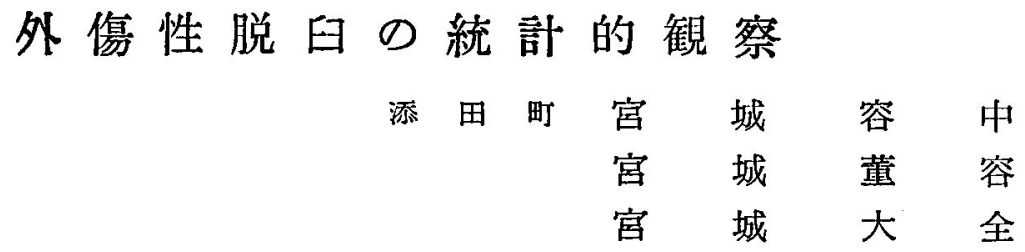

\title{
The Statistical Observations of the Fresh Dislocations
}

By

\author{
Y. Miyagi, T. Miyagi and D. Miyagi \\ Soeda.
}

\section{1) 腥 言}

外傷性脱囦は学折に較べ頻度も少なく，且つ比較的 陳旧例を除き，研究の対䃉となる牙が少なく，珍らし い症例の報告や，或いは一関節のみの!说目に関する報 告がしばしば認められるのみで，綜合的な研究，観祭 は，極く少数の，それも大学病院筑の大都市に於ける

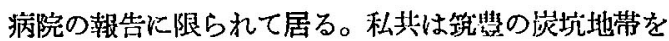
中心とし，一部北九州の工業地带を含さ地域に於て, 過去 3 年間の!|总四患者を調査，統計的に観察し，2，
3 の知見を得たので，交献的考察を肃朴，考按を加之 つ〉報告し，諸䝨の御批判を仰ぎ度いと思う。

\section{2) 総 論}

吾々が過去 3 年間に経験した脱白㭧渚は 403 名で， 之は同じ期間中の外賃患者総数 22,401 名に対して， 堡か $1.8 \%$ であり，又骨折患者の 8,094，(38.1\%)に 比べて可成り低い頻度を示し，飭野比の骨折と脱田比 10 : 1 に対し, 私共の例では，21：1で極めて少なく なつて居る。脱臼を各関節別に見ると,上肢は 355 例, 
表 1 年 令 別 D 各 関 節 脱

\begin{tabular}{|c|c|c|c|c|c|c|c|c|c|c|c|}
\hline 年 令 部 位 & 肩 & 时 & 鎮 & 腕 & 指 & 股。 & 科 & 是 & 趾 & その他 & 計 \\
\hline$\sim 9$ 才 & 0 & 29 & 0 & 0 & 7 & 0 & 0 & 0 & 2 & 0 & 38 \\
\hline $10 才 \sim$ & 5 & 43 & 6 & 4 & 18 & 2 & 2 & 2 & 2 & 0 & 84 \\
\hline $20 / / ~ \sim$ & 18 & 20 & 18 & 7 & 14 & 3 & 2 & 4 & 2 & 2 & 90 \\
\hline $30 / / \sim$ & 12 & 5 & 13 & 5 & 5 & 0 & 0 & 2 & 1 & 1 & 44 \\
\hline $40 / / \sim$ & 16 & 6 & 11 & 4 & 8 & 1 & 0. & 0 & 0 & 3 & 49 \\
\hline $50 / /$ & 20 & 3 & 7 & 6 & 3 & 3 & 0 & 3 & 2 & 3 & 50 \\
\hline $60 / 1 \sim$ & 11 & 2 & 7 & 1 & 3 & 5 & 0 & 0 & 0 & 1 & 30 \\
\hline $70 / 1 \sim$ & 12 & 1 & 1 & 0 & 1 & 0 & 0 & 0 & 0 & 0 & 15 \\
\hline $80 / / \sim$ & 2 & 0 & 1 & 0 & 0 & 0 & 0 & 0 & 0 & 0 & 3 \\
\hline 計 & 96 & 109 & 64 & 27 & 59 & 14 & 4 & 11 & 9 & 10 & 403 \\
\hline
\end{tabular}

(88.9\%)，下肢 35 例 $(8.7 \%)$ で諸家の統計と大差は ない。尚, 残り 10 例は, 顎, 脊椎等の脱臼である。 部位別では, 时関節が最も多く，109例(27.1\%)で 次いで肩関節，鎖骨の関節，指関節，腕関節の順とな つて居る（表 I ）, 又, 性別では男子 309 名 (76.5\%) に対し, 女子 94 名 (23.5\%) で凡そ，3:1の割合と なり, 左右別では右 195 名, 左 202 名で, 左右は大 した差は認られない。年令別では肩，股，腕関節では 40,50 才台の高年者が多く, 时, 手指関節では, 10 才 台を中心とした若年者に多く見られる。この為に全症 例に亘る年令別では従来の Speed, Hoffa 等の統計と 異なり，10，50，40，30才台の順となつて居る。

\section{3) 各 論}

i ）局関節 : 一この関節の脱臼は従来の統計では第 1 位で, 全脱臼の殆んど半数を占めると云はれて居る が, 私共の例では前述の如く, 时関節に次ぐ第 2 位で, $23.8 \%$ である。原因は阥落が最も多く(38 8\%), 次 いで転倒, 喧等となつて居る。脱臼は烏啄下脱臼が 61 例で最も多く, 次いで腋窩脱目 32 例で, 之に肩 胛骨前方脱曰 1 例を含む, 前方脱曰が 96 例中の 94 例 で, 後方脱臼は僅か 2 例にのみ認められた。年令別で は, 50 才台が最も多く，次いで 20 才台で, 以下, 40 , 70, 30 才台となつて居るが，この間に大差はなく， 10 才台は割に少なく，10才以下には 1 例 子見られ ない。

合併症は, 腋窩脱曰に最も多く,(19 例中 13 例) その 種類は上腕骨上端部骨折が 22 例, 肩胛骨々折が 1 例
であつた。又合併症を有する例は 60 才合に最も多く， 111 例中 7 例で, 以下, 50，70 才台となつて居り, 若年者では 20 才台に 1 例見られるのみで, 10,30 才 台では皆無である。通院期間は，合併症の有無により 相違が認められるが，脱臼のみの例では 6 週で治療を 打ら切つたものが最も多く, 次いで 3 週, 2 週で, 平 均 4.4 週となつて居る。

ii）鎖骨の脱臼 : - Gurit は鎖骨の脱臼は全体の $5 \%$ を占めると報告して居るが，私共の例では $15 \%$ の多きを占め，決して少ない数ではない事を示して居 る。原因別では，転倒，隉落（夫々 17 例, $26.5 \%$ ) の 他柔道が多く（15 例, 23.4\%）このために年命別では 20 才台が最も多く(23 例) 次いで 30,40 才台となつ て居る。脱田部位は，肩鎖関節が 64 例中，52 例で， 胸鎖関節は 12 例にすぎない。合併症は鎖骨々折が大 半を占め, 少数の胁骨々折も見られるが，それらは殆 んど 60，50 才台の高年者に見られる。合併症のない 例の治療日数は, 肩鎖, 胸鎖関節共に 3 週間が最も多 く，最長治澺日数は肩鎖関節で 8 週，胸鎖関節で 7 週 となつて居り, 平均日数は肩鎖関節 27 日, 胸鎖関節 25 日である。

iii）时関節 : 一この関節の脱臼は従来は肩関節に次

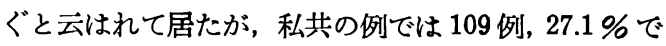
第 1 位を占めて居る。この事は都会の大病院を地方病 院との差にもよるし, 又この脱臼は青少年に多く, 近 代スポーツの興隆, 産業の発展に伴 5 交通網の発達等 の原因で，子供が外傷を蒙むる機会が多くなつている 


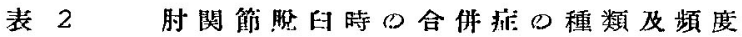

\begin{tabular}{|c|c|c|c|c|c|c|c|c|c|}
\hline 種 類 - 例数 & $-9 \neq$ & $10 / / \sim$ & $20 / 1 \sim$ & $30 / \pi \sim$ & $40 / 1 \sim$ & $50 / 1 \sim$ & $60 / 1 \sim$ & 計 & $\%$ \\
\hline 数 & 29 & 43 & 20 & 5 & 6 & 3 & 2 & 109 & \\
\hline 外顆 骨 折 & 3 & 5 & & & & & & 8 & 12.9 \\
\hline 内上顆 " & 12 & 11 & & 1 & & & & 24 & 38.6 \\
\hline 通 顆 " & 1 & 1 & & & & & & 2 & 3.2 \\
\hline 顆上 & 3 & 4 & & & & & & 7 & 11.2 \\
\hline 上䀯 & & 1 & 1 & & 1 & & 1 & 4 & 6 \\
\hline 峏前膊 & 2 & 1 & & & & & & 3 & 4.8 \\
\hline 筧 胃 & 2 & & 1 & & & 1 & & 4 & 6 \\
\hline 尺岳 & 3 & 4 & 1 & 1 & 1 & & & 10 & 16.1 \\
\hline 計 & 26 & 27 & 3 & 2 & 2 & 1 & 1 & 62 & \\
\hline 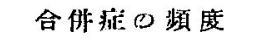 & $90 \%$ & $64 \%$ & $15 \%$ & $40 \%$ & $33.3 \%$ & $33.3 \%$ & $50 \%$ & $56.8 \%$ & \\
\hline
\end{tabular}

事にもよろうが，何よりる，时関節脱臼は比較的に整 復され易く，受㰾居直ちに，所謂整骨師の治㵀を受け 医家の統計に現はれなかつたのが原因しているのでは ないかと考えられる。原因の大半は，転倒，繁落であ るが，前の二関節の場合と異なり，柔道より，密ろ相 撲, 野球が多くなつて居る。脱臼の形態は，両前膊後 方脱臼が 88 例で，その中，後方涚臼 81 例. 側方脱臼 6 例, 前方脱臼 1 例である。前膊単独脱臼は 21 例 で,

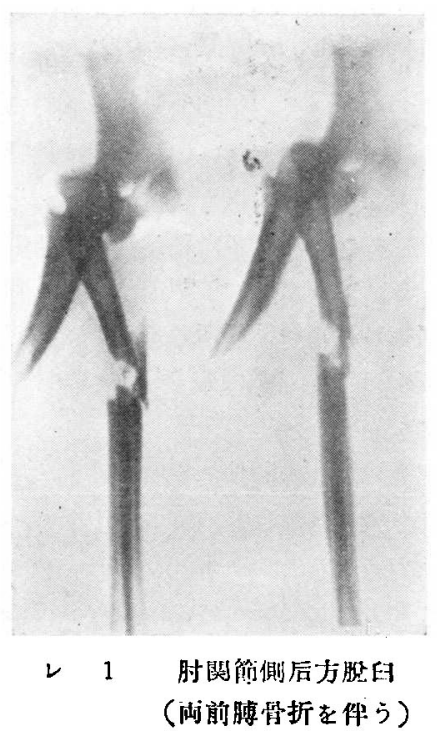

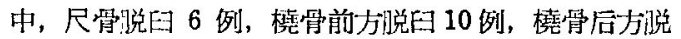
日5例である。

合併症を伴亏ものは 109 例中 62 例 で, 半数上上に 認められ，その中で内上顆常折が最も多く、次いで尺 骨々折で, 両前膊骨折は 3 例飞認められた。（表 2 ) 合併症を年命別㑆ると，10才沦では $90 \%, 10$ 才台 では $64 \%$ に合併症を伴なつて居り，若年者程骨折を 伴 5ものが多い。治潦日数は年命により差があり，10

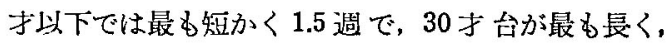
3.6 週で，平均 2 週となつて居る。尚合併症を有する 例では 7 週を要して居る。

iv）獬関節及び腕骨の脱曰: 一この脱曰は 27 例, $7.5 \%$ で第 5 位にあり，原因は交通事故や，学災関係

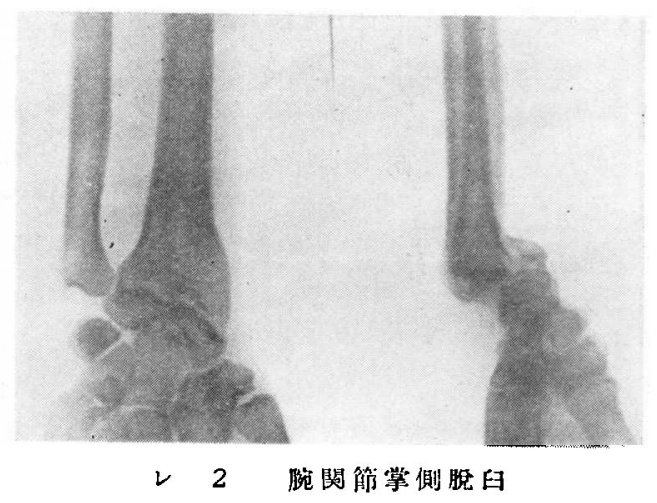


等比較的強力な外力によるものが多く, 27 例中, 23 例 (85.1\%) は合併症を有して居り, その種類は橈骨々 折が 9 例 (39.3\%) で最も多く, 両前膊, 尺骨, 腕骨, 中手骨々折の順となつて居る。その形態は全例共, 掌 側脱臼である。尚，この中には，腕骨の脱臼として， 豆状骨脱臼，月状骨脱臼，腕骨間の脱臼が夫々 1 例宛 に見られる。

v）指関節の脱臼 : 一 この脱田は 59 例 で全体の $14.6 \%$ に相当し，原因も転到の外，野球，喧嘩等とな つて居り，年令的には主として 10，20才台で，総て， 背側脱臼である。各指別の頻度は表(3)の如くで, 拇指 が最も多く, 次いで小指で, 示指が一番少ない。

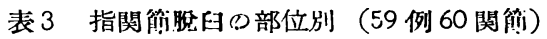

\begin{tabular}{|c|c|c|c|c|c|c|c|}
\hline & 拇 & 示 & 中 & 環 & 小 & 計 & $\%$ \\
\hline 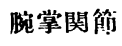 & 1 & 0 & 0 & 1 & 1 & 3 & 5 \\
\hline 掌指 " & 22 & 4 & 1 & 0 & 2 & 29 & 47 \\
\hline 第一指 / & 6 & 1 & 3 & 4 & 2 & 16 & 28 \\
\hline 第二指 "I & & 1 & 4 & 3 & 4 & 12 & 20 \\
\hline 計 & 29 & 6 & 8 & 8 & 9 & 60 & \\
\hline$\%$ & 47 & 9 & 14 & 14 & 16 & & \\
\hline
\end{tabular}

vi）股関節脱目 : 一 この部の脱臼は 14 例, $3.1 \%$ で Gurit の統計 $12.09 \%$ より少なく，Krönleinの $2 \% よ り は$ 稍々高く，諸家の統計と大差はないが順位 は 7 位になつて居る。年令は, 60 才, 50 才台等の高 年者に多く, 原因は, 阥落, 転倒, 交通事故, 労災関 係が多く，合併症を有するものは，3例で，それ等は 総て交通事故によるものである。合併症は骨船骨折 1
例, 大転子骨折 2 例で，脱臼の形態は 13 例 (92.8\%) が後方脱臼で，前方脱臼は 1 例 $(7.1 \%)$ にすぎず, Kneer の統計（前方脱臼 $23.4 \%$ ）に比し著しく低率 となつて居る。

vii）㯟関節 : 一 この部の脱曰は極めて少なく，4 例 (0.9\%) にすぎず，原因は交通事故によるbので, 10,20 才合の若年者に多く見られ，4 例共に脛骨の後 方脱臼である。

viii）足関節部脱田：一この脱眠は 11 例で，原因 は労災関係が，8例で, 墜落, 転倒等が 3 例で, 年令 も，20才台を中心とした居年者に多く，その形態は, 足関節外方脱臼 9 例 で, 内方脱臼は 1 例で, その他 Chopart 関節の脱臼が 1 例認められた。この部の脱田 11 例 9 例に踝部骨折が見られる。

ix）趾脱臼：一この部の脱臼は 9 例で, 指の 59 例 に比し甚だ尠なく，年令も比較的若年者に多く，部位 は第一趾，中足趾関節が最も多く，総てが背側脱臼で ある。

\section{4) 結 語}

i ） 3 年間に於ける外傷性脱田患者は, 403 名で之 は, 全外傷患者の $1.8 \%$ に相当し, 骨折との比は 21 : 1 である。

ii）部位別では肘関節が最も多く，次いで肩，鎖骨 指, 腕関節となつて居る。

iii）肩，股関節脱臼は 50 台，60才台に多く， 时，指，鎖骨，腕関節は 10 才台，20 才台に多い。

iv）此の為に, 全脱臼の年令別では 20 才, 10 才台 が多く，50,40才が之に次いで居る。

v) 性別は男 3 : 女 1 で, 左右別に大差はない。

vi）肩，鎖骨関節は比較的高年者に骨折の合併症が あり, 时関節は若年者程多く, 合併症を有して居る。

関 節 内骨 折 の 運 命

九州労災病院 整形外科 鹿子生 和夫

The Shicksal of the Intra-articular Fractures

By

K. Kako

Kyushu Labour Accidental Hospital, Kokura

(Director : S. Naito)

関節内骨折が如何なる運命を辿るかは興味ある問題 であるが，之に関する業蹟は夏聞にして多くを知らな
い。関節内骨折の運命と云う す, 年令, 性別, 関節別, 単粁或は複雑骨折別, 骨折型, 観察時期, 治潦法等種々 